\title{
Determination of the phytochemical profile, in vitro the antioxidant and antimicrobial activities of essential oil from Arbutus andrachne L. wood growing in Turkey
}

\author{
Yusuf Sıcak $^{a, *}$ (i), Elif Ayşe Erdoğan Eliuz ${ }^{b}$
}

\begin{abstract}
This study aimed to determine the chemical composition, antioxidant and antibacterial activities of the essential oil of Arbutus andrachne L. wood, collected from Köyceğiz region of Muğla. According to GC-MS results 25 compounds were identified, accounting for $80.5 \%$ of the wood oil. The predominant compounds were cinnamyl alcohol (21.97\%), 4-tertbutylcyclohexyl acetate $(16.59 \%)$ and isobornyl acetate $(15.37 \%)$. The investigated wood oil showed significant bioactivities. Furthermore, this study showed that A. andrachne L. essential oil with preferential constituents can be used as potential antioxidant and antibacterial agents for food, perfume and pharmaceutical industries.

Keywords: Arbutus andrachne L., Essential oil, Phytochemical profile, Antioxidant activity, Antimicrobial activity
\end{abstract}

\section{Türkiye'de yetişen Arbutus andrachne L. odununun uçucu yağının fitokimyasal profili, in vitro antioksidan ve antimikrobiyal aktivitelerinin belirlenmesi}

\begin{abstract}
Özet: Bu çalışmada, Muğla'nın Köyceğiz bölgesinden toplanan Arbutus andrachne L. odununun esansiyel yağının kimyasal bileşimi, antioksidan ve antibakteriyel aktiviteleri belirlenmesi amaçlanmıştır. GC-MS sonuçlarına göre, odun yağının \% 80.5'ini oluşturan 25 bileşik tanımlandı. Baskın bileşikler, sinnamil alkol (\% 21.97), 4-tert-butilsikloheksil asetat (\% 16.59) ve izoboril asetat (\% 15.37) idi. İncelenen ağaç yağları önemli biyoaktiviteler gösterdi. Ayrıca, bu çalışma, tercih edilen bileşenlere sahip $A$. andrachne L. uçucu yağının gıda, parfüm ve ilaç endüstrileri için potansiyel antioksidan ve antibakteriyel maddeler olarak kullanılabileceğini göstermiştir.

Anahtar kelimeler: Arbutus andrachne L., Esansiyel yağ, Kimyasal bileşen, Antioksidan aktivite, Antimikrobiyal aktivite
\end{abstract}

\section{Introduction}

Arbutus andrachne L. (Greek or Eastern strawberry tree) is among the two species of Arbutus genus which belongs to the family Ericaceae (Serçe et al., 2010). It is an evergreen small tree which is native to the Mediterranean region and southwestern Asia (Markovski, 2017; Bertsouklis and Papafotiou, 2013; Dönmez et al., 2016). The red coloured edible berries of strawberry tree have traditionally been used for human consumption in many countries (Molina et al., 2011; Tardío et al., 2006; Çavuşoğlu et al., 2015). The Arbutus andrachne L. is called as "Sandal" tree (Dönmez, 2018) and the berries of Arbutus species are called as "Davulga" or "Kocayemis" in Turkey (Şeker and Toplu, 2010). Many food products can be prepared from berries in a wide range including alcoholic beverages (liqueur spirits and wine), jam, fruit jelly and marmalades (Ayaz et al., 2000; Pallauf et al., 2008; Oliveira et al., 2009).

Screening natural plants based essential oils and extracts for biological activity has been a historically significant research field that has resulted in the development of several phytopharmaceuticals, perfumes and natural antioxidant\&antibacterial agents in food industry (Abu-rish et al., 2016; Djouahri et al., 2015; Sicak et al., 2017). In this context, there is an increasing demand on the medicinal plant studies with the essential oils composition and their bioactivity potentials. A. andrachne $\mathrm{L}$. is also a special plant used in folk medicine due to many medicinal properties of its fruits and leaves (e.g. astringent, antidiarrheal, depurative, laxative and urinary antiseptic etc.) (Mostafa et al., 2010; Oliveira et al., 2009). Indeed, the composition and potent antioxidant activity of the extracts of $A$. andrachne $\mathrm{L}$. fruits and leaves has been verified in the preliminary studies (Serçe et al., 2010; Şeker and Toplu, 2010).

To the best of our knowledge there is no comparative work has been published on the evaluation of chemical composition and bioactivity properties of $A$. andrachne $\mathrm{L}$. wood essential oil from Köyceğiz. The aim of the present study was to evaluate chemical composition, antioxidant and antibacterial activity of $A$. andrachne $\mathrm{L}$. wood branch oil obtained by hydrodistillation method. For this purpose, in vitro antioxidant activities were evalauted by using four complementary assays, namely, $\beta$-carotene/linoleic acid assay, cation radical scavenging activity (ABTS assay), free radical scavenging activity (DPPH assay) and cuprac reducing power (CUPRAC assay). In vitro antimicrobial

\footnotetext{
$\triangle$ a Department of Plant and Animal Production, Vocational School of Koycegiz, Muğla Sıtkı Koçman University, Muğla, Turkey

b Department of Food Technology, Vocational School of Technical Sciences, Mersin University, Mersin, Turkey

@ * Corresponding author (İletişim yazarı): ysicak@ gmail.com

$\checkmark \quad$ Received (Geliş tarihi): 10.12.2018, Accepted (Kabul tarihi): 19.03.2019
}

Citation (Atıf): Sıcak, Y., Erdoğan Eliuz, E.A., 2018. Phytochemical profile, in vitro screening of the antioxidant and antimicrobial activities of essential oil from Arbutus andrachne L. wood growing in Turkey. Turkish Journal of Forestry, 20(1): 57-61.

DOI: $\underline{10.18182 / \text { tjf.492749 }}$ 
activities were determined by using broth microdilution method againsts Escherichia coli (ATCC 25293), Bacillus subtilis (ATCC 6633), Staphylococcus aureus (ATCC 25925), Pseudomonas aureginosa, Candida albicans and Candida parapsilosis.

\section{Material and methods}

\subsection{Plant material and Essential oil extraction}

A. andrachne L. wood were collected from Köyceğiz region of Muğla, Turkey in 2017. It was identified at the Herbarium of Biology, Faculty of Science, Muğla Sitk1 Koçman University, Turkey. The plant sample was confirmed by comparing it with the specimen located at the stated herbarium.

The essential oil extraction was performed via hydrodistillation which is generally known to be one of the most extensively used techniques to extract volatile compounds from several matrix (Golmakani and Rezaei, 2008). The essential oil was obtained from approximately $100 \mathrm{~g}$ of the dried A. andrachne L. wood by hydrodistillation method for 2 hours. The resulting mixture was taken to the separation funnel and liquid-liquid extraction was performed by adding hexane to the water-oil mixture. Anhydrous magnesium sulphate was added to the organic phase and the water in the mixture was filtered to remove the salt. Finally, the solvent of the organic phase was removed using the rotary evaporator under vacuum.

\subsection{Chemical composition}

The qualitative and quantitative composition of essential oil analysis were conducted at Giresun University central Research Laboratories Application and Research Center by GC-MS 7890A-(5975C inert MSD) instrument equipped with an Agilent 19091S-433 column (30m X $250 \mu \mathrm{m}$ film X $0.25 \mu \mathrm{m}$ thickness). Helium was used as a carrier gas. The temperature was raised from $50^{\circ} \mathrm{C}$ to $270^{\circ} \mathrm{C}$ by an increase of $5^{\circ} \mathrm{C} /$ minutes and then 25 minutes of waiting time were implemented during the analysis. Injection port and detector temperatures were $250^{\circ} \mathrm{C}$ and $260^{\circ} \mathrm{C}$, respectively. Characterization of essential oil components was based on the library (Wiley and NIST) comparison with the mass spectra of the injected essential oil samples.

\subsection{Antioxidant activity}

Solutions of essential oil of $A$. andrachne L. were prepared at four different concentrations as 400-200-100-50 ppm in EtOH. EtOH was used as a control, while BHA and $\alpha$-tocopherol $(\alpha$-TOC) were used as antioxidant standards for comparison of the activity tests. The results were given as $50 \%$ concentration $\left(\mathrm{IC}_{50}\right)$ for $\mathrm{ABTS}^{+}$scavenging activity, $\beta$-carotene-linoleic acid and $\mathrm{DPPH}^{\circ}$ assay while in the CUPRAC assay are expressed as $\mathrm{A}_{0.5}$.

The spectrophometric analysis of antioxidant activities were performed according to the literature procedures as follows: $\mathrm{ABTS}^{+}$scavenging activity (Re et. al., 1989), $\beta$ carotene-linoleic acid (Marco, 1968; Öztürk et. al., 2011), CUPRAC assay (Apak et. al., 2004) and DPPH ${ }^{\circ}$ scavenging activity (Blois, 1958).

\subsection{Antimicrobial activity}

The antimicrobial activity of essential oil of $A$. andrachne $\mathrm{L}$. were researched on several pathogens, namely Escherichia coli (ATCC 25293), Bacillus subtilis (ATCC 6633), Staphylococcus aureus (ATCC 25925), Pseudomonas aureginosa, Candida albicans and Candida parapsilosis using modified spectrophotometric microdilution technique. Firstly, the inoculums of microorganisms were prepared in $4 \mathrm{~mL}$ Triptic Soy Broth for bacteria, $4 \mathrm{~mL}$ Sabouraud Dextrose Broth for yeasts and incubated at $37^{\circ} \mathrm{C}$, overnight. After 24 hours, the culture suspensions were adjusted to 0.5 McFarland Standard Turbidity $\left(\sim 10^{4}\right.$ for bacteria, $\left(\sim 10^{3}\right.$ for yeasts $)$ and stored at $+4^{\circ} \mathrm{C}$ until use (McFarland, 1987).

The $50 \mu \mathrm{L}(415 \mu \mathrm{g} / \mathrm{mL})$ of A. andrachne oil were dissolved at $1 \mathrm{~mL}$ with dimethyl sulfoxide (10\% DMSO). The experiment were performed on 96-well microtiter plates and firstly $50 \mu \mathrm{L}$ of Mueller Hinton Broth (MHB) medium were added into all wells. Two-fold serial dilutions of $50 \mu \mathrm{L}$ oil was made on all $\mathrm{x}$-axis along of elisa plate. Columns 11 and 12 were used as negative and positive controls. Finally, $10 \mu \mathrm{L}$ culture of microorganisms was inoculated on all wells except medium control wells. All of the plates were incubated at $37^{\circ} \mathrm{C}$ for 24 hours, the growth (turbidity) was measured at $600 \mathrm{~nm}$ for bacteria, $415 \mathrm{~nm}$ for yeasts. For MIC analysis, the optical density was read both before, T0 and after 24 hours-incubation, T24. For each plate, MIC were calculated using the following formula: The OD for each replicate at T0 was subtracted from the OD for each replicate at T24. The Percent growth $=($ ODtest $/ O D$ control)x100. Percent Inhibition $=1-(\mathrm{OD}$ test well/OD of corresponding control well)x100 for each row of the 96-well plate.

The dose-response curves obtained from plotting the linear of the concentration of the oils against the resulting percent inhibition of microbial growth were obtained with the regression analysis, giving an $\mathrm{R}^{2}$ value. MIC (the lowest concentration of test material which results in $99.9 \%$ or $50 \%$ inhibition of growth) were calculated using the $\mathrm{R}^{2}$ formula on inhibition curve (Patton et al., 2006; Erdoğan et al., 2017).

\subsection{Statistical analysis}

All data on biological activity assay studies were the averages of triplicate analysis. All the results are presented as $50 \%$ concentration $\left(\mathrm{IC}_{50}\right)(\%)$. Data were recorded as mean \pm SEM (standard error of the mean). Significant differences between means were determined by Student's-t test and $p$ values $<0.05$ were regarded as significant.

The SPSS-one way ANOVA, Tukey test were performed for between MICs and \% Cell viability values. The experiment was repeated at least 3 times. Differences were considered significant at $p \leq 0.05$.

\section{Results and discussion}

\subsection{Chemical composition}

The components of essential oil from A. andrachne L. were detected by comparing the relative retention times and mass spectra from data library. The results of the chemical 
composition of the essential oil are presented in Table 1. It was reported that the $A$. andrachne $\mathrm{L}$. oil were mainly composed of cinnamyl alcohol (21.97\%), isobornyl acetate $(15.37 \%)$ and also containing 4-tert-butylcyclohexyl acetate $(16.59 \%)$, isoamyl salicylate $(7.44 \%)$. The dihyrdocoumarin $(5.75 \%)$, acetylcedrene $(5.06 \%)$, santolina epoxide $(4.70 \%)$, ancistronaphthoic acid (3.16\%) and 6-(2-methylcyclohexyl)2,4-xylenol (1.66\%) were presented in smaller quantities.

\subsection{Antioxidant activity}

The in vitro antioxidant activity of essential oil obtained from the wood of $A$. andrachne L. collected from KöyceğizTurkey was reported in this study for the first time. The antioxidant activity results of $A$. andrachne L. essential oil given Table 2. According to the $\beta$-carotene/ linoleic acid assay results, the oil exhibited better lipid peroxidation inhibitory activity value of $\left(\mathrm{IC}_{50}\right) 3.22 \pm 0.18 \mu \mathrm{g} / \mathrm{mL}$ than standard $\alpha$-TOC $\left(\mathrm{IC}_{50}=4.48 \pm 0.17 \mu \mathrm{g} / \mathrm{mL}\right)$. In the ABTS ${ }^{+}$ assay, essential oil ( IC $_{50}: 3.47 \pm 0.22 \mu \mathrm{g} / \mathrm{mL}$ ) showed better cation radical scavenging activity than standard $\alpha$-TOC $\left(\mathrm{IC}_{50}=54.97 \pm 0.99 \mu \mathrm{g} / \mathrm{mL}\right)$. The essential oil demonstrated activity $\mathrm{IC}_{50}$ value of $48.31 \pm 0.13 \mu \mathrm{g} / \mathrm{mL}$ in $\mathrm{DPPH}$ free scavenging activity, than standard $\mathrm{BHT}\left(\mathrm{IC}_{50}=54.80 \pm 0.78\right.$ $\mu \mathrm{g} / \mathrm{mL}$ ). The essential oil indicated better the CUPRAC activity with an $\mathrm{A}_{0.5}$ value of $27.25 \pm 0.01 \mu \mathrm{g} / \mathrm{mL}$, than $\alpha$ TOC $\left(\mathrm{A}_{0.5}=40.55 \pm 0.04 \mu \mathrm{g} / \mathrm{mL}\right)$ using as a pharmaceutical standard.

It is prominent to point out that the antioxidant activity of the essential oils depends on the species, harvest time and geographical attitude (Mechergui et al., 2016) which can be explained by fact that the oils chemical composition varies because of extrinsic and intrinsic factors (Dutra et al., 2019). The determined antioxidant activities were related to compounds, such as cinnamyl alcohol, isobornyl acetate and 4-tert-butylcyclohexyl acetate which are commonly presented in the essential oils. It was shown that cinnamyl alcohol have significant DPPH scavenning potential (Suryanti et al., 2018).
The 4-tert-butylcyclohexyl acetate extracted from Decalepis hamiltoni was also found to be an effective antioxidant agent (Rayar and Manivannan, 2015).

\subsection{Antimicrobial activity}

The 24 hours incubation of $A$. andrachne L. oil with microorganisms was found to be statistically significant in terms of the resultant cell viability $(p<0.05)$ (Table 3 ). Accordingly, the lowest cell viability value 24-time incubation with $A$. andrachne $\mathrm{L}$. oil were obtained in $C$. parapsilosis culture $(48.28 \%)$, while the highest cell viability was in P. aureginosa $(90.2 \%)$.

Generally, all tested microorganisms were sensitive to $A$. andrachne $\mathrm{L}$. oil at $\mathrm{MIC}_{99.9}$ range of $8.3-18.9 \mu \mathrm{g} / \mathrm{mL}$. The $\mathrm{MIC}_{99.9}$ and $\mathrm{MIC}_{50}$ of $A$. andrachne L. oil results for $E$. coli was 9.7 and $5.8 \mu \mathrm{g} / \mathrm{mL}$, B. subtilis 12.1 and $7.03 \mu \mathrm{g} / \mathrm{mL}, S$. aureus 18.9 and $11.7 \mu \mathrm{g} / \mathrm{mL}, C$. albicans 13.4 and $7.2 \mu \mathrm{g} / \mathrm{L}$, C. parapsilosis 8.3 and $5.3 \mu \mathrm{g} / \mathrm{mL}$ and $P$. aureginosa 10.1 and $7.5 \mu \mathrm{g} / \mathrm{mL}$ (Figure 1). Therefore, the maximum antimicrobial activity were determined against $C$. parapsilosis $(8.3 \mu \mathrm{g} / \mathrm{mL})$ while the minimum activity were determined against $S$. aureus $(18.9 \mu \mathrm{g} / \mathrm{mL})$.

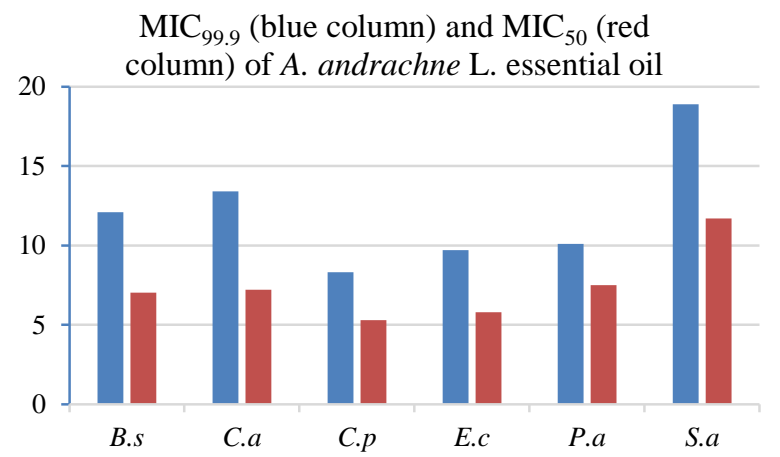

Figure 1. The comparison of $\mathrm{MIC}_{99.9}$ and $\mathrm{MIC}_{50}(\mu \mathrm{g} / \mathrm{mL})$ values of $A$. andrachne $\mathrm{L}$. oil against $B$. subtilis, $C$. albicans, C. parapsilosis, E. coli, P. aureginosa and $S$. aureus

Table 1. Chemical composition of A. andrachne L. essential oil

\begin{tabular}{|c|c|c|c|c|c|}
\hline $\begin{array}{c}\mathrm{RT}^{\mathrm{a}} \\
(\mathrm{min})\end{array}$ & Component & $\begin{array}{c}\text { Quantity }^{\mathrm{b}} \\
(\%)\end{array}$ & $\begin{array}{c}\mathrm{RT}^{\mathrm{a}} \\
(\mathrm{min})\end{array}$ & Component & $\begin{array}{c}\text { Quantity }^{\mathrm{b}} \\
(\%)\end{array}$ \\
\hline 10.606 & D-Limonene & 1.76 & 24.979 & Dihydrocoumarin & 5.75 \\
\hline 13.381 & 2-Propanol,1,1'-oxylbis & 0.58 & 25.883 & $\alpha$-Bulnesene & 1.08 \\
\hline 18.410 & Citronellol & 1.07 & 27.949 & Isoamyl salicylate & 7.44 \\
\hline 18.702 & 1,8-Iridadiene & 0.45 & 30.140 & Patchouli alcohol & 1.35 \\
\hline 19.303 & Geraniol & 1.00 & 32.252 & $\begin{array}{l}\text { 2-methoxy-4,4-dimethyl-6-phenylcyclohexa-2,5- } \\
\text { dien-1-one }\end{array}$ & 0.58 \\
\hline 20.058 & Isobornyl acetate & 15.37 & 32.378 & $\begin{array}{l}\text { 2,2,6-trimethyl-1-(2-methyl-cyclobut-2-enyl)- } \\
\text { hepta-4,6-dien-3-one }\end{array}$ & 0.33 \\
\hline 21.872 & Cinnamyl alcohol & 21.97 & 32.692 & Acetylcedrene & 5.06 \\
\hline 22.462 & 4-tert-butylcyclohexyl acetate & 16.59 & 32.961 & 4,5,6,7-tetrahydro-3-indolinone & 0.98 \\
\hline 23.600 & Caryophyllene & 0.20 & 33.099 & 6-(2-methylcyclohexyl)-2,4-xylenol & 1.66 \\
\hline 23.926 & Vanilline & 0.47 & 33.202 & Bicyclopentylidene & 0.55 \\
\hline 24.069 & $\alpha$-Guaiene & 0.77 & 33.253 & Ancistronaphthoic acid & 3.16 \\
\hline 24.213 & Seychellene & 0.38 & 34.106 & Santolina epoxide & 4.70 \\
\hline 24.562 & $\alpha$-Patchoulene & 0.29 & & & \\
\hline
\end{tabular}

${ }^{\mathrm{a}} \mathrm{RT}$ : Retention time, ${ }^{\mathrm{b}}$ Quantity (\%): more than 0.2 . 
Table 2. Antioxidant activity of A. andrachne L. essential oil ${ }^{\mathrm{a}}$

\begin{tabular}{|c|c|c|c|c|}
\hline \multirow[b]{2}{*}{ Sample } & \multicolumn{4}{|c|}{ Antioxidant Activity } \\
\hline & $\begin{array}{c}\beta \text {-carotene/ linoleic acid } \\
\text { assay } \\
\mathrm{IC}_{50}(\mu \mathrm{g} / \mathrm{mL})\end{array}$ & $\begin{array}{l}\text { ABTS }^{\cdot+} \text { assay } \\
\mathrm{IC}_{50}(\mu \mathrm{g} / \mathrm{mL})\end{array}$ & $\begin{array}{l}\mathrm{DPPH}^{\bullet} \text { assay } \\
\mathrm{IC}_{50}(\mu \mathrm{g} / \mathrm{mL})\end{array}$ & $\begin{array}{c}\text { CUPRAC assay } \\
\mathrm{A}_{0.50}(\mu \mathrm{g} / \mathrm{mL})\end{array}$ \\
\hline Essential oil & $3.22 \pm 0.18$ & $3.47 \pm 0.22$ & $48.31 \pm 0.13$ & $27.25 \pm 0.01$ \\
\hline $\mathrm{BHT}^{\mathrm{b}}$ & $2.31 \pm 0.11$ & $2.97 \pm 0.05$ & $54.80 \pm 0.78$ & $3.92 \pm 0.04$ \\
\hline$\alpha-$ TOC $^{\mathrm{b}}$ & $4.48 \pm 0.17$ & $4.95 \pm 0.30$ & $12.21 \pm 0.06$ & $40.44 \pm 0.03$ \\
\hline
\end{tabular}

${ }^{\mathrm{a}}$ Value represent the means \pm standard deviation of three parallel measurements $(p<0.05)$

${ }^{\mathrm{b}}$ Reference compound

Table 3. Statistical analysis of average \% cell viability variation of microorganisms incubated with A. andrachne L. oil for 24 hours according to spectrophotometric microdilution method. The difference between the average MIC and \% cell viability of microorganism groups were compared according to the SPSS_ANOVA (Tukey) test.

\begin{tabular}{lccc}
\hline & $\mathrm{MIC}_{99.9}$ & $\mathrm{MIC}_{50}$ & Cell viability \% \\
\hline B. subtilis & $12.1^{*} \pm 0.2$ & $7.03^{*} \pm 0.02$ & $64.99 \pm 10.6$ \\
C. albicans & $13.4^{*} \pm 0.5$ & $7.2^{*} \pm 0.01$ & $69.14 \pm 8.6$ \\
C. parapsilosis & $8.3 \pm 1.5$ & $5.3 \pm 1.7$ & $48.28^{*} \pm 16.12$ \\
E. coli & $9.7^{*} \pm 0.3$ & $5.8^{*} \pm 0.5$ & $54.14 \pm 12.33$ \\
P. aureginosa & $10.1^{*} \pm 0.01$ & $7.5^{*} \pm 0.1$ & $90.2 * \pm 20.2$ \\
S. aureus & $18.9 \pm 6.2$ & $11.7 \pm 3.3$ & $92.4 \pm 10.9$ \\
\hline
\end{tabular}

*: Differences were considered significant at $p \leq 0.05$.

Although there is a few information in literature about A. andrachne L. oil's antimicrobial performance, extracts prepared from A. unedo, another type of Arbutus genus, leaves were showed antimicrobial effeciency against many microorganisms B. cereus, B. subtilis, S. aureus and $S$. epidermis, E. coli and P. aeruginosa and C. albicans, $C$. krusei, C. parapsilosis and C. glabrata at range of 0.1-20 $\mathrm{mg} / \mathrm{mL}$ (Malheiro et al., 2012). In the study of Orak et al. (2011), antimicrobial and antioxidant activities of ethanol and methanol extracts of Arbutus unedo leaves were investigated to detemine a correlation between the extract and activity. The extracts showed no inhibitory effect against Escherichia coli, while the extracts exhibited antibacterial activity against $S$. aureus at concentration of $250 \mathrm{mg} / \mathrm{mL}$. In the antioxidant assay, the $\mathrm{EC}_{50}$ values of extracts were found between $0.42 \mathrm{mg} / \mathrm{mL}$ and $0.65 \mathrm{mg} / \mathrm{mL}$ (Orak et al., 2011). In another study, the methanolic, ethanolic, ethyl acetate and $n$-hexanic extracts from the leaves of Arbutus unedo exhibited an antibacterial activity against Escherichia coli, Staphylococus aureus, Listeria monocytogenes and Pseudomonas aeruginosa between the MIC of $0.2 \mathrm{mg} / \mathrm{mL}$ and $8 \mathrm{mg} / \mathrm{mL}$ (Bouyahya et al., 2016). In Kahraman and coworkers's study, the major component of essential oil extracted from Arbutus unedo flower and fruit were reported to be terpineol $(16.3 \%)$ and hexadecanoic acid, respectively. In addition, they were showed moderate antibacterial activity against Listeria monocitogenes and Enterococcus faecalis (Kahraman et al., 2010).

These findings indicate that the antimicrobial and antioxidant activity of $A$. andrachne could be mainly attributed to its major compounds as given in previous studies. For example, Cinnamomum zeylanicum (cinnamon), rich in cinnamyl alcohol $(8.21 \%)$, was reported to have strong antimicrobial and antioxidant activity (El-Baroty et al., 2010; Chang et al., 2001). The essential oil obtained from the leaves of Chamaecyparis obtusa, rich in isobornyl acetate, were found to have strong antibacterial activities against Gram (+) bacteria such as $S$. aureus, Bacillus cereus and some fungi such as $C$. albicans, $C$. tropicalis (Yang et al., 2007).

\section{Conclusion}

The wood essential oils have shown to have significant bioactivities including antibacterial, antioxidant, antiviral, antifungal and insecticide. The essential oil of A. andrachne after successive extraction were analysed by GC-MS. The cinnamyl alcohol, 4-tert-butylcyclohexyl acetate and isobornyl acetate was determined in the chemical characterization of the essential oil of A. andrachne as major compounds. The antimicrobial activity of essential oil was effective in the control of $B$. subtilis, $C$. albicans, $C$. parapsilosis, E. coli, P. aureginosa and $S$. aureus, which may be related to the well antioxidant activity of the components present in oil, such as cinnamyl alcohol, isobornyl acetate and 4-tert-butylcyclohexyl acetate. This study showed that $A$. andrachne L. essential oil with preferential constituents can also be used as potential antioxidant and antibacterial agents for food, perfume and pharmaceutical industries. Moreover, the findings obtained from biological activity assays showed that A. andrachne $L$. essential oil have been a promising candidate for the discovery of new drugs and the preparation of new natural products for aromatherapy and phytotherapy applications. However, furture in vivo studies should be carried out to verify such actions in different matrices.

\section{References}

Abu-rish, E.Y., Kasabri, V., Hudaib, M.M., Mashalla, S.H., AlAlawi, L.H., Tawaha, K., Mohammad, M.K., Mohamed, Y.S., Bustanji, Y., 2016. Evaluation of antiproliferative activity of some traditional anticancer herbal remedies from Jordan. Tropical Journal of Pharmaceutical Research, 15(3): 469-474.

Apak, R., Güçlü, K., Özyürek, M., Karademir, S.E., 2004. Novel total antioxidant capacity index for dietary polyphenols and vitamins $\mathrm{C}$ and $\mathrm{E}$, using their cupric ion reducing capacity in the presence of neocuproine: cuprac method. Journal of Agricultural and Food Chemistry, 52: 7970-7981.

Ayaz, F.A., Küçükislamoğlu, M., Reunanen, M., 2000. Sugar, nonvolatile and phenolic acids composition of strawberry tree (Arbutus unedo L. var. ellipsioidea) fruits. Journal of Food Composition and Analysis, 13: 171-177.

Bertsouklis, K.F., Papafotiou, M., 2013. Seed germination of Arbutus unedo, A. andrachne and their natural hybrid $A$. andrachnoides in relation to temperature and period of storage. Hortscience, 48(3): 347-351.

Blois, M.S., 1958. Antioxidant determinations by the use of a stable free radical. Nature, 181: 1199-1200.

Bouyahya, A., El Moussaoui, N., Abrini, J., Bakri, Y., Dakka, N., 2016. Determination of phenolic contents, antioxidant and antibacterial activities of Strawberry Tree (Arbutus unedo L.) Leaf Extracts. British Biotechnology Journal, 14: 1-10. 
Chang, S.T., Chen, P.F., Chang, S.C., 2001. Antibacterial activity of leaf essential oils and their constituents from Cinnamomum osmophloeum. Journal of Ethnopharmacology, 77: 123-127.

Çavuşoğlu, A., Sulusoğlu, M., Erkal, S., 2015. Biotechnological approaches in strawberry tree (Arbutus unedo L.) breeding. Journal of Crop Breeding and Genetics, 1(1): 36-41.

Djouahri, A., Boualem, S., Aoumeur Baaliouamer, L.B., 2015. Geographic's variation impact on chemical composition, antioxidant and anti-inflammatory activities of essential oils from wood and leaves of Tetraclinis articulata (Vahl) Masters. Industrial Crops and Products, 63: 138-146.

Dutra, T.V., Castro, J.C., Menezes, J.L., Ramos, T.R., Prado, I.N., Junior, M.M., Graton Mikcha, J.M., Abreu Filho, B.A., 2019. Bioactivity of oregano (Origanum vulgare) essential oil against Alicyclobacillus spp. Industrial Crops \& Products, 129: 345349.

Dönmez, İ.E., 2018. Lipophilic and hydrophilic extractives from Strawberry tree (Arbutus andrachne L.) and oriental plane (Platanus orientalis L.). Wood, Applied Ecology and Environmental Research, 16: 741-747.

Dönmez, İ.E., Hemming, J., Willför, S.M., 2016. Bark extractives and suberin monomers from Arbutus andrachne and Platanus orientalis. BioResources, 11: 2809-2819.

El-Baroty, G.S, Abd El-Baky, H.H., Farag, R.S., Saleh, M.A. 2010. Characterization of antioxidant and antimicrobial compounds of cinnamon and ginger essential oils. African Journal of Biochemistry Research, 4: 167-174.

Erdoğan Eliuz, E.A., Ayaş, D., Gökşen, G., 2017. In vitro phototoxicity and antimicrobial activity of volatile oil obtained from aromatic plants. Journal of Essential Oil Bearing Plants, 20: 758-768

Golmakani, M.T., Rezaei, K., 2008. Comparison of microwaveassisted hydrodistillation with the traditional hydrodistillation method in the extraction of essential oils from Thymus vulgaris L. Food Chemistry, 109: 925-930.

Kahraman, N., Albay, C.G., Dogan, N., Usta, A., Karaoglu, S.A., Yayla, N., 2010. Volatile constituents and antimicrobial activities from flower and fruit of Arbutus unedo L. Asian Journal of Chemistry, 22: 6437-6442.

Malheiro, R., Sa, O., Pereire, E., Aguiar, C., Baptista, P., Pereira, J.A., 2012. Arbutus unedo L. leaves as source of phytochemicals with bioactive properties. Industrial Crops and Products, 37(1): 473-478.

Marco, G.J., 1968. A rapid method for evaluation of antioxidants. Journal of The American Oil Chemists' Society, 45: 594-598.

Markovski, A., 2017. Morphological characteristics of greek strawberry tree (Arbutus andrachne L.) genotypes. Acta Agriculturae Serbica, 44: 193-2061.

McFarland, J., 1987. Standardizasyon bacteria culture for the disc diffusion assay. The Journal of the American Medical Association, 49: 1176-1178

Mechergui, K., Jaouadi, W., Coelho, J.P., Khouja, M.L., 2016. Effect of harvest year on production, chemical composition and antioxidant activities of essential oil of oregano (Origanum vulgare subsp. glandulosum (Desf.) letswaart) growing in North Africa. Industrial Crops \& Products, 90: 32-37.

Molina, M., Pardo-De-Santayana, M., Aceituno, L., Morales, R., Tardío, J., 2011. Fruit production of strawberry tree (Arbutus unedo L.) in two Spanish forests. Forestry, 84(4): 419-429.
Mostafa, S.E., Karam, N.S., Shibli, R.A., Alali, F.Q., 2010. Micropropagation and production of arbutin in oriental strawberry tree (Arbutus andrachne L.). Plant Cell, Tissue and Organ Culture, 103: 111-121.

Oliveira, I., Coelho, V., Baltasar, R., Pereira, J.A., Baptista, P., 2009. Scavenging capacity of strawberry tree (Arbutus unedo L.) leaves on free radicals. Food and Chemical Toxicology, 47: 1507-1511.

Orak, H.H., Yagar, H., Isbilir, S.S., Demirci, A.Ș., Gümüș, T., Ekinci, N., 2011. Evaluation of antioxidant and antimicrobial potential of Strawberry Tree (Arbutus unedo L.) Leaf. Food Science and Biotechnology, 20: 1249-1256.

Öztürk, M., Kolak, U., Topçu, G., Öksüz, S., Chourdhary, M.I., 2011. Antioxidant and anticholinestrease activite constituents from Micromeria cilicica by radical-scavenging activityguided fractionation. Food Chemistry, 126: 31-38.

Pallauf, K., Rivas-Gonzalo, J.C., Castillo, M.D., Cano, M.P., Pascual-Teresa, S., 2008. Characterization of the antioxidant composition of strawberry tree (Arbutus unedo L.) fruits. Journal of Food Composition and Analysis, 21: 273-281.

Patton, T., Barett, J., Brennan, J., Moran, N., 2006. Use of a spectrophotometric bioassay for determination of microbial sensitivity to manuka honey. Journal of Microbiological Methods, 6484-6495.

Rayar, A., Manivannan, R., 2015. Evaluation of in vitro antioxidant potential of ethanolic extract and 4-tert-butylcyclohexyl acetate isolated from Decalepis hamiltonii wight and arn seed. World Journal of Pharmacy and Pharmaceutical Sciences, 4: 1649-1662.

Re, R., Pellegrini, N., Proteggente, A., Pannala, A., Yang, M., Rice-Evans, C., 1989. Antioxidant activity applying an improved ABTS radical cation decolorization assay. Free Radical Biology \& Medicine, 26: 1231-1237.

Şeker, M., Toplu, C., 2010. Determination and comparison of chemical characteristics of Arbutus unedo L. and Arbutus andrachnae L. (Family Ericaceae) fruits. Journal of Medicinal Food, 13(4): 1013-1018.

Serçe, S., Özgen, M., Alkan Torun, A., Ercișli, S., 2010. Chemical composition, antioxidant activities and total phenolic content of Arbutus andrachne L. (Fam. Ericaceae) (the Greek strawberry tree) fruits from Turkey. Journal of Food Composition and Analysis, 23: 619-623.

Sıcak, Y., Büyüksakallı, H., Malkoçoğlu, S., Özler, M.A., Öztürk, M., 2017. Antioxidant, anticholinesterase inhibitory and tyrosinase inhibitory activities of Iris xanthospuria extracts growing in Köyceğiz region. Journal of Ongoing Chemical Research, 3(1): 22-31.

Suryanti, V., Wibowo, F.R., Khotijah, S., Andalucki, N., 2018. Antioxidant activities of cinnamaldehyde derivatives. OP Conf. Series: Materials Science and Engineering, 333.

Tardío, J., Pardo-de-Santayana, M., Morales, R., 2006. Ethnobotanical review of wild edible plants in Spain. Botanical Journal of Linnean Society, 152: 27-72.

Yang, J.K., Choi, M.S., Seo, W.T., Rinker, D.L., Han, S.W., Cheong, G.W., 2007. Chemical composition and antimicrobial activity of Chamaecyparis obtusa leaf essential oil. Fitoterapia, 78: 149-152. 